\title{
$12: 51777716-51782391$
}

National Cancer Institute

\section{Source}

National Cancer Institute. 12:51777716-51782391. NCI Thesaurus. Code C42525.

Physical location of IGFBP6_Gene 